\title{
Differential effects of experimentally induced anxiety and fear on pain: the role of anxiety sensitivity [Corrigendum]
}

Metzger S, Poliakov B, Lautenbacher S. J Pain Res. 2019;12:1791-1801.

On page 1791, in the abstract conclusion section the sentence "This indicates that subclinical AS levels are suffi- cient to increase pain sensitivity, in uncertain situations." should read "This indicates that clinically relevant AS levels are sufficient to increase pain sensitivity, in uncertain situations."

\section{Publish your work in this journal}

The Journal of Pain Research is an international, peer reviewed, open access, online journal that welcomes laboratory and clinical findings in the fields of pain research and the prevention and management of pain. Original research, reviews, symposium reports, hypothesis formation and commentaries are all considered for publication. The manuscript management system is completely online and includes a very quick and fair peer-review system, which is all easy to use. Visit http:// www.dovepress.com/testimonials.php to read real quotes from published authors. 